Chapman University

Chapman University Digital Commons

Education Faculty Articles and Research

College of Educational Studies

1986

\title{
Teacher Education and the Politics of Engagement: The Case for Democratic Schooling
}

Henry A. Giroux

Miami University, Ohio

Peter McLaren

Chapman University, mclaren@chapman.edu

Follow this and additional works at: http://digitalcommons.chapman.edu/education_articles

Part of the Curriculum and Social Inquiry Commons, Educational Administration and Supervision Commons, and the Educational Sociology Commons

\section{Recommended Citation}

Giroux, H. A., \& McLaren, P. (1986). Teacher education and the politics of engagement: The case for democratic schooling.Harvard Educational Review, 56(3): 213-238.

This Article is brought to you for free and open access by the College of Educational Studies at Chapman University Digital Commons. It has been accepted for inclusion in Education Faculty Articles and Research by an authorized administrator of Chapman University Digital Commons. For more information, please contact laughtin@chapman.edu. 


\section{Teacher Education and the Politics of Engagement: The Case for Democratic Schooling}

\section{Comments}

This article was originally posted in Harvard Educational Review, volume 56, issue 3, in 1986.

\section{Copyright}

Harvard Education Publishing Group 


\title{
Teacher Education and the Politics of Engagement: The Case for Democratic Schooling
}

\author{
HENRY A. GIROUX \\ PETER MCLAREN \\ Miami University, Ohio
}

Henry A. Giroux and Peter McLaren argue that many of the recently recommended publicschool reforms either sidestep or abandon the principles underlying education for a democratic citizenry developed by John Dewey and others in the early part of this century. Yet, Giroux and McLaren believe that this historical precedent suggests a way of reconceptualizing teaching and public schooling which revives the values of democratic citizenship and social justice. They demonstrate that teachers, as "transformative intellectuals," can reclaim space in schools for the exercise of critical citizenship via an ethical and political discourse that recasts, in emancipatory terms, the relationships between authority and teacher work, and schooling and the social order. Moreover, the authors outline a teacher education curriculum that links the critical study of power, language, culture, and history to the practice of a critical pedagogy, one that values student experience and student voice.

In presenting this essay, the editors of HER hope to initiate a dialogue that will continue in the November special issue, "Teachers, Teaching, and Teacher Education." We believe that Giroux and McLaren's provocative ideas serve well to usher in this discussion; they remind us also of the complexity of the issues which we as educators and as students confront in attempting to promote progressive forms of social, political, and intellectual life.

As far back as 1890, a teacher from New England named Horace Willard cogently argued that in contrast to members of other professions, teachers lived "lives of mechanical routine, and were subjected to a machine of supervision, organization, classification, grading, percentages, uniformity, promotions, tests, examination." Nowhere, Willard decried, was there room in the school culture for "individuality, ideas, independence, originality, study, investigation." ${ }^{2}$ Forty years later Henry

\footnotetext{
${ }^{1}$ Arthur G. Powell, "University Schools of Education in the Twentieth Century," Peabody Journal of Education, 54 (1976), 4.

2 Powell, "University Schools," p. 4.
}

Harvard Educational Review Vol. 56 No. 3 August 1986 Copyright $(\odot$ by President and Fellows of Harvard College 0017-8055/86/0800-0213\$01.25/0 
W. Holmes, dean of Harvard University's new Graduate School of Education, echoed these sentiments in his criticism of the National Survey of the Education of Teachers in 1930. According to Holmes, the survey failed to support teachers as independent critical thinkers. Instead, it endorsed a view of the teacher as a "routine worker under the expert direction of principals, supervisors, and superintendents." 3 Holmes was convinced that if teachers' work continued to be defined in such a narrow fashion, schools of education would eventually respond by limiting themselves to forms of training that virtually undermined the development of teachers as critically-minded intellectuals.

At different times both of these noteworthy critics of American education recognized that any viable attempt at educational reform must address the issue of teacher education. Most important was their conviction that teachers should function professionally as intellectuals, and that teacher education should be inextricably linked to critically transforming the school setting and, by extension, the wider social setting.

In the early part of the century, a number of experimental teacher education programs managed to shift the terrain of struggle for democratic schooling from a largely rhetorical platform to the program site itself. One such program was organized around New College, an experimental teacher training venture affiliated with Columbia University, Teachers College between 1927 and 1953. Spokespersons from New College proclaimed "that a sound teacher education program must lie in a proper integration of rich scholarship, educational theory, and professional practice." "Furthermore, New College embarked on a training program based on the principle that "it is the peculiar privilege of the teacher to play a large part in

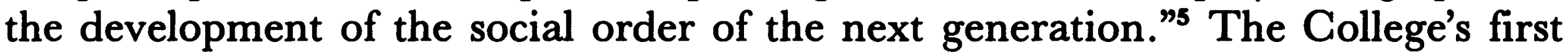
announcement claimed that if teachers were to escape from the usual "academic lock step ... [they] required contact with life in its various phases and understanding of it - an understanding of the intellectual, moral, social, and economic life of the people."

The idea that teacher education programs should center their academic and moral objectives on the education of teachers as critical intellectuals, while simultaneously advancing democratic interests, has invariably influenced the debates revolving around the various "crises" in education over the last fifty years. ${ }^{7}$ Moreover, it has been precisely because of the presence of such an idea that a rationale eventually could be constructed which linked schooling to the imperatives of democracy and classroom pedagogy to the dynamics of citizenship. This is not to suggest, however, that either public education or teacher training programs were overburdened by a concern for democracy and citizenship. ${ }^{8}$ Nevertheless, the his-

\footnotetext{
${ }^{3}$ George Counts, quoted in Powell, "University Schools," p. 4.

4 As quoted in Lawrence A. Cremin, David A. Shannon, and Mary Evelyn Townsend, A History of Teachers College, Columbia University (New York: Columbia University Press, 1954), p. 222.

${ }^{3}$ Cremin, Shannon, and Townsend, $A$ History, p. 222.

- As quoted by George Counts in Cremin, Shannon, and Townsend, A History, p. 222.

7 For an interesting discussion of this issue, see Ira Katznelson and Margaret Weir, Schooling for All: Class, Race, and the Decline of the Democratic Ideal (New York: Basic Books, 1985).

- See esp. the work of the revisionist historians of the 1960s. Among the representative works are Michael B. Katz, The Irony of Early School Reform: Educational Innovation in Mid-Nineteenth Century Massachusetts (Boston: Beacon Press, 1968); Colin Greer, The Great School Legend (New York: Basic Books,
} 
torical precedent for educating teachers as intellectuals and developing schools as democratic sites for social transformation might begin to define the way in which public education and the education of teachers could be appropriately perceived today. We wish, in other words, to build upon this precedent in order to argue for the education of teachers as transformative intellectuals. We use the term "intellectual" in the manner described by Frank Lentricchia:

By "intellectual" I do not mean what traditional Marxism has generally meant - a bearer of the universal, the political conscience of us all. Nor do I mean "a radical intellectual" in the narrowest of understandings of Antonio Gramsci-an intellectual whose practice is overtly, daily aligned with and empirically involved in the working class. By intellectual I refer to the specific intellectual described by Foucault - one whose radical work of transformation, whose fight against repression is carried on at the specific institutional site where he finds himself and on the terms of his own expertise, on the terms inherent to his own functioning as an intellectual. ${ }^{9}$

By the term "transformative intellectual," we refer to one who exercises forms of intellectual and pedagogical practice which attempt to insert teaching and learning directly into the political sphere by arguing that schooling represents both a struggle for meaning and a struggle over power relations. We are also referring to one whose intellectual practices are necessarily grounded in forms of moral and ethical discourse exhibiting a preferential concern for the suffering and struggles of the disadvantaged and oppressed. Here we extend the traditional view of the intellectual as someone who is able to analyze various interests and contradictions within society to someone capable of articulating emancipatory possibilities and working towards their realization. Teachers who assume the role of transformative intellectuals treat students as critical agents, question how knowledge is produced and distributed, utilize dialogue, and make knowledge meaningful, critical, and ultimately emancipatory. ${ }^{10}$

We argue in this paper that within the current discourse on educational reform ${ }^{11}$ there exists, with few exceptions, ${ }^{12}$ an ominous silence regarding the role that both teacher education and public schooling should play in advancing democratic practices, critical citizenship, and the role of the teacher as intellectual. Given the legacy of democracy and social reform bequeathed to us by our educational forebears, such as John Dewey and George Counts, this silence not only suggests that

1972); and Clarence J. Karier, Paul Violas, and Joel Spring, Roots of Crisis: American Education in the Twentieth Century (Chicago: Rand McNally, 1973).

${ }^{9}$ Lentricchia, Criticism and School Change (Chicago: University of Chicago Press, 1983), pp. 6-7.

${ }^{10}$ See Stanley Aronowitz and Henry A. Giroux, Education under Siege: The Conservative, Liberal, $\mathcal{E}^{\circ}$ Radical Debate over Schooling (South Hadley, MA: Bergin \& Garvey, 1985).

${ }^{11}$ We are using the term "discourse" to mean "a domain of language use subject to rules of formation and transformation," as quoted in Catherine Belsey, Critical Practice (London: Methuen, 1980, p. 160). Discourses may also be described as "the complexes of signs and practices which organize social existence and social reproduction. In their structured, material persistence, discourses are what give differential substance to membership of a social group or class or formation, which mediate an internal sense of belonging, and outward sense of otherness," as quoted in Richard Terdiman, Discourse-Counter-Discourse (New York: Cornell University Press, p. 54).

${ }^{12-}$ Aronowitz and Giroux, Education under Siege; and Ann Bastian, Colin Greer, Norm Fruchter, Marilyn Gittel, and Kenneth Haskins, Choosing Equality: The Case for Democratic Schooling (New York: New World Foundation, 1985). 
some of the current reformers are suffering from political and historical amnesia; it also points to the ideological interests that underlie their proposals. Regrettably, such interests tell us less about the ills of schooling than they do about the nature of the real crisis facing this nation - a crisis which, in our view, not only augurs poorly for the future of American education, but underscores the need to reclaim a democratic tradition presently in retreat. Bluntly stated, much of the current literature on educational reform points to a crisis in American democracy itself.

The discourse of recent educational reform characteristically excludes certain proposals from consideration. For instance, missing from the various privileged discourses that have fashioned the recent reform movement, and absent among the practices of public school teachers whose participation in the current debate on education has been less than vigorous, are concerted attempts at democratizing schools and empowering students to become critical, active citizens. This reluctance on the part of teachers has had a particularly deleterious effect, since the absence of proposals for rethinking the purpose of schools of education around democratic concerns has further strengthened the ideological and political pressures that define teachers as technicians and structure teacher work in a demeaning and overburdening manner. Kenneth Zeichner underscores this concern when he writes:

It is hoped that future debate in teacher education will be more concerned with
the question of which educational, moral and political commitments ought to
guide our work in the field rather than with the practice of merely dwelling on
which procedures and organizational arrangements will most effectively help us
realize tacit and often unexamined ends. Only after we have begun to resolve
some of these necessarily prior questions related to ends should we concentrate on
the resolution of more instrumental issues related to effectively accomplishing our
goals. ${ }^{13}$

The current debate provides an opportunity to critically analyze the ideological and material conditions - both in and out of schools - that contribute to teacher passivity and powerlessness. We also believe that recognition of the failure to link the purposes of public schooling to the imperatives of economic and social reform provides a starting point both for examining the ideological shift in education that has taken place in the 1980s and for developing a new language of democracy, empowerment, and possibility in which teacher education programs and classroom practices can be defined. Our central concern is in developing a view of teacher education that defines teachers as transformative intellectuals and schooling as part of an ongoing struggle for democracy. In developing our argument, we will focus on four considerations. First, we will analyze the dominant new conservative positions that have generated current educational reforms in terms of the implications these viewpoints hold for the reorganization of teacher education programs. Second, we will develop a rationale for organizing teacher education programs around a critical view of teacher work and authority, one that we believe is consistent with the principles and practices of democracy. Third, we will present some programmatic suggestions for analyzing teacher education as a form of cultural 8.

${ }^{13}$ Zeichner, "Alternative Paradigms of Teacher Education," Journal of Teacher Education, 34 (1983), 
politics. Finally, we will argue for a critical pedagogy that draws upon the manysided conversations and voices that make up community life.

\section{Education Reform and the Retreat from Democracy}

Underlying the educational reforms proposed by the recent coalition of conservatives and liberals, conveniently labeled "the new conservatives," is a discourse that both edifies and mystifies their proposals. Capitalizing upon the waning confidence of the general public and a growing number of teachers in the effectiveness of public schools, the new conservatives argue for educational reform by faulting schools for a series of crises that include everything from a growing trade deficit to the breakdown of family morality. ${ }^{14}$ As is the case with many public issues in the age of Ronald Reagan, the new conservatives have seized the initiative by framing their arguments in a terse rhetoric that resonates with a growing public concern about downward mobility in hard economic times, that appeals to a resurgence of chauvinistic patriotism, and that points toward a reformulation of educational goals along elitist lines. Such a discourse is dangerous not only because it misconstrues the responsibility schools have for wider economic and social problems - a position that has been convincingly refuted and need not be argued against here ${ }^{15}$ - but also because it reflects an alarming ideological shift regarding the role schools should play in relation to society. The effect of this shift, launched by the new right's full-fledged attack on the educational and social reforms of the $1960 \mathrm{~s}$, has been to redefine the purpose of education so as to eliminate its citizenship function in favor of a narrowly defined labor market perspective. The essence and implications of this position have been well-documented by Barbara Finkelstein.

Contemporary reformers seem to be recalling public education from its traditional utopian mission - to nurture a critical and committed citizenry that would stimulate the processes of political and cultural transformation and refine and extend the workings of political democracy. . . . Reformers seem to imagine public schools as economic rather than political instrumentalities. They forge no new visions of political and social possibilities. Instead, they call public schools to industrial and cultural service exclusively. . . . Reformers have disjoined their calls for educational reform from calls for a redistribution of power and authority, and the cultivation of cultural forms celebrating pluralism and diversity. As if they have had enough of political democracy, Americans, for the first time in a one hundred and fifty-year history, seem ready to do ideological surgery on their public

\footnotetext{
${ }^{14}$ Some of the more representative writing on this issue can be found in Diane Ravitch, The Troubled Crusade: American Education 1945-1980 (New York: Basic Books, 1983); John H. Bunzel, ed. Challenge to American Schools: The Case for Standards and Values (New York: Oxford University Press, 1985); Ravitch, The Schools We Deserve: Reflections on the Educational Crises of Our Time. (New York: Basic Books, 1985); and Edward Wynne, "The Great Tradition in Education: Transmitting Moral Values," Educational Leadership, 43 (1985), 7.

${ }^{15}$ Some of the best analyses are Lawrence C. Stedman and Marshall S. Smith, "Recent Reform Proposals for American Education," Contemporary Education Review, 53 (1983), 85-104; Walter Feinberg, "Fixing the Schools: The Ideological Turn," Issues in Education, 3 (1985), 113-138; Edward H. Berman, "The Improbability of Meaningful Educational Reform," Issues in Education, 3 (1985), 99112; Michael Apple, "National Reports and the Construction of Inequality," British Journal of Sociology of Education, in press; and Aronowitz and Giroux, Education under Siege.
} 
schools - cutting them away from the fate of social justice and political democracy completely and grafting them onto elite corporate, industrial, military, and cultural interests. ${ }^{16}$

It is important to recognize that the new conservative attack on the reforms of the last decade has resulted in a shift away from defining schools as agencies of equity and justice. There is little concern with how public education could better serve the interests of diverse groups of students by enabling them to understand and gain some control over the sociopolitical forces that influence their destinies. Rather, via this new discourse, and its preoccupation with accountability schemes, testing, accreditation, and credentializing, educational reform has become synonymous with turning schools into "company stores." It now defines school life primarily by measuring its utility against its contribution to economic growth and cultural uniformity. Similarly, at the heart of the present ideological shift is an attempt to reformulate the purpose of public education around a set of interests and social relations that define academic success almost exclusively in terms of the accumulation of capital and the logic of the marketplace. This represents a shift away from teacher control of the curriculum and toward a fundamentally technicist form of education that is more directly tied to economic modes of production. Moreover, the new conservatives provide a view of society in which authority derives from technical expertise and culture embodies an idealized tradition that glorifies hard work, industrial discipline, domesticated desire, and cheerful obedience. Edward Berman has deftly captured the political nature of this ideological shift.

Architects of the current reform have, to their credit, dropped the rhetoric about the school as a vehicle for personal betterment. There is little pretense in today's reports or the resultant programs that individual improvement and social mobility are important concerns of a reconstituted school system. The former rhetoric about individual mobility has given way to exhortations to build educational structures that will allow individual students to make a greater contribution to the economic output of the corporate state. There are few rhetorical flourishes to obfuscate this overriding objective. ${ }^{17}$

The ideological shift that characterizes the current reform period is also evident in the ways in which teacher preparation and classroom pedagogy are currently being defined. The rash of reform proposals for reorganizing schools points to a definition of teacher work that seriously exacerbates conditions which are presently eroding the authority and intellectual integrity of teachers. In fact, the most compelling aspect of the influential reports, especially the widely publicized $A N a$ tion at Risk, Action for Excellence, and $A$ Nation Prepared: Teachers for the 21st Century, is their studious refusal to address the ideological, social, and economic conditions underlying poor teacher and student performance. ${ }^{18}$ For example, as Frankenstein

\footnotetext{
${ }^{16}$ Finkelstein, "Education and the Retreat from Democracy in the United States, 1979-198?," Teachers College Record, 86 (1984), 280-281.

${ }^{17}$ Berman, "Improbability," p. 103.

${ }^{18}$ We are using the term "influential" to refer to those reports that have played a major role in shaping educational policy at both the national and local levels. These include The National Commission on Excellence in Education, $A$ Nation at Risk: The Imperative for Educational Reform (Washington, DC:
} 
and Louis Kampf point out, public school teachers constantly confront conditions "such as the overwhelming emphasis on quantification (both in scoring children and keeping records), the growing lack of control over curriculum (separating conception from execution) and over other aspects of their work, the isolation from their peers, the condescending treatment by administrators, and the massive layoffs of veteran teachers." 19

Instead of addressing these issues, many of the reforms taking place at the state level further consolidate administrative structures and prevent teachers from collectively and creatively shaping the conditions under which they work. For instance, at both the local and federal levels, the new educational discourse has influenced a number of policy recommendations, such as competency-based testing for teachers, a lockstep sequencing of materials, mastery learning techniques, systematized evaluation schemes, standardized curricula, and the implementation of mandated "basics." 20 The consequences are evident not only in the substantively narrow view of the purposes of education, but also in the definitions of teaching, learning, and literacy that are championed by the new management-oriented policymakers. In place of developing critical understanding, engaging student experience, and fostering active and critical citizenship, schools are redefined through a language that emphasizes standardization, competency, and narrowly-defined performance skills.

Within this paradigm, the development of curricula is increasingly left to administrative experts or simply adopted from publishers, with few, if any, contributions from teachers who are expected to implement the new programs. In its most ideologically offensive form, this type of prepackaged curriculum is rationalized as teacher-proof and is designed to be applied to any classroom context regardless of the historical, cultural, and socioeconomic differences that characterize various schools and students. ${ }^{21}$ What is important to note is that the deskilling of teachers

GPO, 1983); Task Force on Education for Economic Growth, Education Commission of the States, Action for Excellence: A Comprehensive Plan to Improve Our Nation's Schools (Denver: Education Commission of the States, 1983); The Twentieth Century Fund Task Force on Federal Elementary and Secondary Education Policy, Making the Grade (New York: The Twentieth Century Fund, 1983); Carnegie Corporation, Education and Economic Progress: Toward a National Education Policy (New York: Author, 1983); and Carnegie Forum on Education and the Economy, A Nation Prepared: Teachers for the 21st Century (Hyattsville, MD: Author, 1986).

Also considered are other recent reports on teacher education reform: The National Commission for Excellence in Teacher Education, $A$ Call for Change in Teacher Education (Washington, DC: American Association of Colleges in Teacher Education, 1985); C. Emily Feistritzer, The Making of a Teacher (Washington, DC: National Center for Education Information, 1984); “Tomorrow's Teachers: A Report of the Holmes Group" (East Lansing, MI: Holmes Group, Inc., 1986); and Francis A. Maher and Charles H. Rathbone, "Teacher Education and Feminist Theory: Some Implications for Practice," American Journal of Education, 101 (1986), 214-235. For an analysis of many of these reports see Catherine Cornbleth, "Ritual and Rationality in Teacher Education Reform," Educational Researcher, 15, No. 4 (1986), 5-14.

19 Frankenstein and Kampf, "Preface," in Sara Freedman, Jane Jackson, and Katherine Boles, "The Other End of the Corridor: The Effect of Teaching on Teachers," Radical Teacher, 23 (1983), 2-23. It is worth noting that the Carnegie Forum's $A$ Nation Prepared ends up defeating its strongest suggestions for reform by linking teacher empowerment to quantifying notions of excellence.

${ }_{20}$ Stedman and Smith, "Recent Reform Proposals," pp. 85-104.

${ }^{21}$ We are not automatically opposed to all forms of curricular software and technologies, such as interactive video disks and computers, as long as teachers become aware of the limited range of applications and contexts in which these technologies may be put to use. Certainly, we agree that some 
appears to go hand-in-hand with the increasing adoption of management-type pedagogies.

Viewing teachers as semiskilled, low-paid workers in the mass production of education, policymakers have sought to change education, to improve it, by "teacherproofing" it. Over the past decade we have seen the proliferation of elaborate accountability schemes that go by acronyms like MBO (management by objectives), PBBS (performance-based budgeting systems), CBE (competency-based education), CBTE (competency-based teacher education), and MCT (minimum competency testing). ${ }^{22}$

The growing removal of curriculum development and analysis from the hands of teachers is related to the ways technocratic rationality is used to redefine teacher work. This type of rationality increasingly takes place within a social division of labor in which thinking is removed from implementation and the model of the teacher becomes that of the technician or white-collar clerk. Likewise, learning is reduced to the memorization of narrowly defined facts and isolated pieces of information that can easily be measured and evaluated. The significance of the overall effects of this type of rationalization and bureaucratic control on teacher work and morale has been forcefully articulated by Linda Darling-Hammond. She writes:

In a Rand study of teachers' views of the effect of educational policies on their classroom practices, we learned from teachers that in response to policies that prescribe teaching practices and outcomes, they spend less time on untested subjects, such as science and social studies; they use less writing in their classrooms in order to gear assignments to the format of standardized tests; they resort to lectures rather than classroom discussions in order to cover the prescribed behavioral objectives without getting "off the track"; they are precluded from using teaching materials that are not on prescribed textbook lists, even when they think these materials are essential to meet the needs of some of their students; and they feel constrained from following up on expressed student interests that lie outside of the bounds of mandated curricula . . . . And 45 percent of the teachers in this study told us that the single thing that would make them leave teaching was the increased prescriptiveness of teaching content and methods - in short, the continuing deprofessionalization of teaching. ${ }^{23}$

The ideological interests that inform the new conservative proposals are based on a view of morality and politics that is legitimated through an appeal to custom, national unity, and tradition. Within this discourse, democracy loses its dynamic character and is reduced to a set of inherited principles and institutional arrange-

prepackaged curricula are more salient than others as instruments of learning. Too often, however, the use of such curricula ignores the contexts of the immediate classroom situation, the larger social milieu, and the historical juncture of the surrounding community. Furthermore, classroom materials designed to simplify the task of teaching and to make it more cost-efficient often separate planning or conception from execution. Many of the recent examples of predesigned commercial curricula are largely focused on competencies measured by standardized tests, precluding the possibility that teachers and students will be able to act as critical thinkers. See Michael W. Apple and Kenneth Teitelbaum, "Are Teachers Losing Control of Their Skills and Curriculum?" Journal of Curriculum Studies, 18 (1986), 177-184.

${ }_{22}$ Darling-Hammond, "Valuing Teachers: The Making of a Profession," Teachers College Record, 87 (1985) 209-218.

${ }^{23}$ Darling-Hammond, "Valuing Teachers," p. 209. 
ments that teach students how to adapt rather than to question the basic precepts of society. What is left in the new reform proposals is a view of authority constructed around a mandate to follow and implement predetermined rules, to transmit an unquestioned cultural tradition, and to sanctify industrial discipline. Couple these problems with large classes, excessive paperwork, fragmented work periods, and low salaries, and it comes as no surprise that teachers are increasingly leaving the field. ${ }^{24}$

In effect, the ideological shift at work here points to a restricted definition of schooling, one that almost completely strips public education of a democratic vision where citizenship and the politics of possibility are given serious consideration. When we argue that the recent conservative or "blue-ribbon" reform recommendations lack a politics of possibility and citizenship, we mean that primacy is given to education as economic investment, that is, to pedagogical practices designed to create a school-business partnership and make the American economic system more competitive in world markets. A politics of possibility and citizenship, by contrast, refers to a conception of schooling in which classrooms are seen as active sites of public intervention and social struggle. Moreover, this view maintains that possibilities exist for teachers and students to redefine the nature of critical learning and practice outside of the imperatives of the corporate marketplace. The idea of a politics and project of possibility is grounded in Ernst Bloch's idea of "natural law" wherein "the standpoint of the victims of any society ought to always provide the starting point for the critique of that society." 25 Such a politics defines schools as sites around which struggles should be waged in the name of developing a more just, humane, and equitable social order both within and outside of schools.

We have spent some time analyzing the new conservative discourse and the ideological shift it represents because in our view the current reforms, with few exceptions, pose a grave threat to both public schooling and the nature of democracy itself. The definition of teaching and learning provided by this discourse ignores, as we have pointed out, the imperative of viewing schools as sites of social transformation where students are educated to become informed, active, and critical citizens. The gravity of this ideological shift is hardly ameliorated by the fact that even public schooling's more liberal spokespersons have failed to develop a critical discourse that challenges the hegemony of dominant ideologies. For example, the highly publicized reports by John Goodlad, Theodore Sizer, Ernest Boyer, and others neither acknowledge nor utilize the radical tradition of educational scholarship. ${ }^{26}$ While the liberal position does take the concepts of equality of opportunity

${ }^{24}$ For an excellent theoretical analysis of this issue, see Freedman, Jackson, and Boles, "The Other End of the Corridor. For a more traditional statistical treatment, see Darling-Hammond, Beyond the Commission Reports: The Coming Crisis in Teaching, R-3177-RC (Santa Monica, CA: Rand Corporation, July 1984); National Education Association, Nationwide Teacher Opinion Poll, 1983 (Washington, DC: Author, 1983); and American Federation of Teachers, School As a Workplace: The Realities of Stress, Vol. I (Washington, DC: Author, 1983).

${ }^{25}$ Dennis J. Schmidt, "Translator's Introduction: In the Spirit of Bloch," in Ernst Bloch, Natural Law and Human Dignity, trans. Dennis J. Schmidt (Boston: MIT Press, 1986), p. xviii.

26 Goodlad, A Place Called School: Prospects for the Future (New York: McGraw-Hill, 1983); Sizer, Horace's Compromise: The Dilemma of the American High School (Boston: Houghton Mifflin, 1984); and Boyer, High School: A Report on Secondary Education in America (New York: Harper \& Row, 1983). 
and citizenship seriously, we are, nevertheless, left with analyses of schooling that lack a sufficiently critical understanding of the ways in which power has been used to favor select groups of students over others. In addition, we are given only a cursory treatment of the political economy of schooling, with its scattered history of dishonorable linkages to corporate interests and ideology. Furthermore, we are provided with little understanding of how the hidden curriculum in schools works in a subtly discriminating way to discredit the dreams, experiences, and knowledges associated with students from specific class, racial, and gender groupings. ${ }^{27}$

In the absence of any competing critical agenda for reform, the new conservative discourse encourages teacher education institutions to define themselves primarily as training sites that provide students with the technical expertise required to find a place within the corporate hierarchy. Thomas Popkewitz and Allan Pitman have characterized the ideology underlying the current reform proposals, moreover, as betraying a fundamental elitism since it basically adopts a perspective of society that is undifferentiated by class, race, or gender. The logic endemic to these reports, the authors argue, demonstrates an attachment to possessive individualism and instrumental rationality. In other words: "Quantity is seen as quality. Procedural concerns are made objects of value and moral domains. The teacher is a facilitator . . . or a counselor. . . . Individualization is pacing through a common curriculum ... . Flexibility in instruction is to begin "where the student is ready to begin' . . . There is no discussion of what is to be facilitated or the conceptions of curriculum to guide procedures."28

Furthermore, Popkewitz and Pitman see a distinctive shift from a concern with equity to a slavish regard for a restricted notion of excellence. That is, the concept of excellence that informs these new reports "ignores the social differentiations while providing political symbols to give credibility to education which only a few can appreciate."29 What is rightly being stressed is that the concept of excellence fashioned in the reports is designed to benefit "those who have already access to positions of status and privilege through accidents of birth."30

Given the context in which teaching and learning are currently being defined, it becomes all the more necessary to insist on an alternative view of teacher education, one which, in refusing to passively serve the existing ideological and institutional arrangements of the public schools, is aimed at challenging and reforming them.

\section{Teacher Education: Democracy and the Imperative of Social Reform}

We want to return to the idea that the fundamental concerns of democracy and critical citizenship should be central to any discussion of the purpose of teacher education. In doing so, we will organize our discussion around two arguments.

\footnotetext{
${ }^{27}$ For an overview and critical analysis of this literature, see Henry A. Giroux, "Theories of Reproduction and Resistance in the New Sociology of Education: A Critical Analysis," Harvard Educational Review, 53 (1983), 257-293.

${ }^{28}$ Popkewitz and Pitman, "The Idea of Progress and the Legitimation of State Agendas: American Proposals for School Reform," Curriculum and Teaching, 1 (1986), p. 21.

${ }^{29}$ Popkewitz and Pitman, "The Idea of Progress," p. 20.

30 Popkewitz and Pitman, "The Idea of Progress," p. 22.
} 
The first represents an initial effort to develop a critical language with which to reconstruct the relationship between teacher education programs and the public schools, on the one hand, and public education and society on the other. The second, and more detailed, argument presents a view of authority and teacher work that attempts to define the political project we believe should underlie the purpose and nature of teacher education programs.

If teacher education programs are to provide the basis for democratic struggle and renewal in our schools, they will have to redefine their current relationship to such institutions. As it presently stands, schools of education rarely encourage their students to take seriously the imperatives of social critique and social change as part of a wider emancipatory vision. If and when education students begin to grapple with these concerns at the classroom level, it is invariably years after graduation. Our own experiences in teacher education institutions - both as students and as instructors - have confirmed for us what is generally agreed to be commonplace in most schools and colleges of education throughout the United States: that these institutions continue to define themselves essentially as service institutions which are generally mandated to provide the requisite technical expertise to carry out whatever pedagogical functions are deemed necessary by the various school communities in which students undertake their practicum experiences. ${ }^{31}$ In order to escape this political posture, teacher education programs need to reorient their focus to the critical transformation of public schools rather than to the simple reproduction of existing institutions and ideologies. ${ }^{32}$

One starting point would be to recognize the importance of educating students in the languages of critique and possibility; that is, providing teachers with the critical terminology and conceptual apparatus that will allow them not only to critically analyze the democratic and political shortcomings of schools, but also to develop the knowledge and skills that will advance the possibilities for generating curricula, classroom social practices, and organizational arrangements based on and cultivating a deep respect for a democratic and ethically-based community. In effect, this means that the relationship of teacher education programs to public schooling would be self-consciously guided by political and moral considerations. Dewey expressed well the need for educators to make political and moral considerations a central aspect of their education and work when he distinguished between "education as a function of society" and "society as a function of education." ${ }^{33}$ In

${ }^{31}$ Zeichner, "Alternative Paradigms"; and Jesse Goodman, "Reflections on Teacher Education: A Case Study and Theoretical Analysis," Interchange, 15 (1984), 7-26. The fact that many teacher education programs have defined themselves as synonymous with instructional preparation has often given them a debilitating practical slant, leading to a limited conception of teaching as exercises in classroom management and control. Isolated courses on classroom management have had a tragic effect on how teachers are able to critically interrogate the political implications of curricular decisionmaking and policy development. This predicament can be traced to a history of the academic politics that grew out of the separation of colleges of education from the liberal arts tradition and the arts and sciences faculty; see Donald Warren, "Learning from Experience: History and Teacher Education," Educational Researcher, 14, No. 10 (1985), 5-12.

${ }^{32}$ For an excellent analysis of this issue, see National Coalition of Advocates for Students, Barriers to Excellence: Our Children at Risk (Boston: Author, 1985).

${ }^{33}$ As quoted in Frank Lentricchia, Criticism and Social Change (Chicago: University of Chicago Press, 1985); see also Dewey, Democracy and Education (New York: Free Press, 1916) and The Public and Its Problems (New York: Holt, 1927). 
simple terms, Dewey's distinction reminds us that education can function either to create passive, risk-free citizens or to create a politicized citizenry educated to fight for various forms of public life informed by a concern for justice, happiness, and equality. At issue here is whether schools of education are to serve and reproduce the existing society or to adopt the more critical role of challenging the social order so as to develop and advance its democratic imperatives. Also at issue is developing a rationale for defining teacher education programs in political terms that make explicit a particular view of the relationship between public schools and the social order, a view based on defending the imperatives of a democratic society.

\section{Public Schools as Democratic Public Spheres}

Our second concern is directed to the broader question of how educators should view the purpose of public schooling. Our position echoes Dewey in that we believe public schools need to be defined as democratic public spheres. This means regarding schools as democratic sites dedicated to self- and social empowerment. Understood in these terms, schools can be public places where students learn the knowledge and skills necessary to live in a critical democracy. Contrary to the view that schools are extensions of the workplace or front-line institutions in the corporate battle for international markets, schools viewed as democratic public spheres center their activities around critical inquiry and meaningful dialogue. In this case, students are given the opportunity to learn the discourse of public association and civic responsibility. Such a discourse seeks to recapture the idea of a critical democracy that commands respect for individual freedom and social justice. Moreover, viewing schools as democratic public spheres provides a rationale for defending them, along with progressive forms of pedagogy and teacher work, as agencies of social reform. When defined in these terms, schools can be defended as institutions that provide the knowledge, skills, social relations, and vision necessary to educate a citizenry capable of building a critical democracy. That is, school practice can be rationalized in a political language that recovers and emphasizes the transformative role that schools can play in advancing the democratic possibilities inherent in the existing society. ${ }^{34}$

\section{Authority and Intellectuals: Rethinking the Nature and Purpose of Teacher Work}

Redefining the notion of authority in emancipatory terms is central to understanding and legitimating teacher work as a critical practice. The importance of such a task can be made clearer by highlighting the significance of authority as part of the fundamental discourse of schooling.

First, as a form of legitimation, authority is inescapably related to a particular vision of what schools should be as part of a wider community and society. Thus, questions about school and teacher authority help to make both visible and problematic the presuppositions of the officially sanctioned discourses and values that legitimate the institutional and social arrangements constituting everyday life in

\footnotetext{
${ }^{34}$ Dewey, "Creative Democracy - The Task Before Us," in Classic American Philosophers, ed. Max Fisch (New York: Appleton-Century-Crofts, 1951), pp. 389-394; and Richard J. Bernstein, "Dewey and Democracy: The Task Ahead of Us," in Post-Analytic Philosophy, ed. John Rajchman and Cornell West (New York: Columbia University Press, 1985) pp. 48-62.
} 
schools. For example, questions might be raised about the nature and source of the authority which legitimates a particular type of curriculum, the way school time is organized, the political consequences of tracking students, the social division of labor among teachers, and the patriarchal basis of authority. In this way, the concept of authority raises issues about the ethical and political basis of schooling. That is, it calls into serious question the role that school administrators and teachers play as intellectuals in both articulating and implementing their particular views or ideologies. In short, the category of authority reinserts the primacy of the political into the language of schooling by highlighting the social and ideological function that educators serve in elaborating, enforcing, and legitimating schooling as a particular form of social life, that is, as a particular set of ideas and practices that occur within historically defined contexts.

Second, if the concept of authority is to provide a legitimating basis for rethinking the purpose and meaning of teacher education, it must be reconstituted around a view of community life in which morality in everyday existence is fundamental to the meaning of democracy. ${ }^{35} \mathrm{~A}$ form of emancipatory authority needs to be developed, one that can illuminate the connection and importance of two questions that teacher education programs should take as a central point of inquiry in structuring the form and content of their curricula. These are: What kind of society do educators want to live in? What kind of teaching and pedagogy can be developed and legitimated by a view of authority that takes democracy and critical citizenship seriously? Authority, in this view, rests on the assumption that public schooling should promote forms of morality and sociality in which students learn to encounter and engage social differences and diverse points of view. In addition, schools should prepare students for making choices regarding forms of life that have morally different consequences. This means that educators must replace pedagogical practices which emphasize disciplinary control and one-sided character formation with practices that are based on an emancipatory authority, ones which enable students to engage in critical analysis and to make choices regarding what interests and knowledge claims are most desirable and morally appropriate for living in a just and democratic state. Equally important is the need for students to engage in civic-minded action in order to remove the social and political constraints that restrict the victims of this society from leading decent and humane lives.

A reconstituted notion of emancipatory authority suggests, in this case, that teachers are bearers of critical knowledge, rules, and values through which they consciously articulate and problematize their relationship to each other, to students, to subject matter, and to the wider community. This view of authority exposes and challenges the dominant view of teachers as primarily technicians or public servants whose role is to implement rather than to conceptualize pedagogical practice. Moreover, the category of emancipatory authority dignifies teacher work by viewing it as an intellectual practice with respect to both its formal characteristics and the nature of the content discussed. Teacher work becomes a form of intellectual labor opposed to the pedagogical divisions between conception and

\footnotetext{
${ }^{35}$ Henry A. Giroux, "Authority, Intellectuals and the Politics of Practical Learning," Teachers College Record (in press).
} 
practice, and production and implementation, that are currently celebrated in a number of educational reforms. The concept of teacher as intellectual carries with it the political and ethical imperative to judge, critique, and reject those approaches to authority that reinforce a technical and social division of labor that silences and disempowers both teachers and students. In other words, emancipatory authority is a concept which demands that teachers and others critically confront the ideological and practical conditions which enable or constrain them in their capacity as transformative intellectuals.

It is important to stress that the concept of emancipatory authority provides the theoretical basis for defining teachers not merely as intellectuals but, more specifically, as transformative intellectuals. The distinction is important because transformative intellectuals are not merely concerned with empowerment in the conventional sense, that is, with giving students the knowledge and skills they will need to gain access to some traditional measure of economic and social mobility in the capitalist marketplace. Rather, for transformative intellectuals, the issue of teaching and learning is linked to the more political goal of educating students to take risks and to struggle within ongoing relations of power in order to alter the oppressive conditions in which life is lived. To facilitate this goal, transformative intellectuals need to make clear the nature of the appeals to authority they are using to legitimate their pedagogical practices. In other words, educators need to specify the political and moral referents for the authority they assume in teaching particular forms of knowledge, in taking stands against forms of oppression, and in treating students as if they ought also to be concerned about social justice and political action.

In short, this reconstituted version of authority is important because it contains elements of a language of both criticism and possibility. As part of the language of critique, the notion of emancipatory authority provides a discourse through which educators can critically examine views of authority often used by conservatives and others to link the purpose of schooling to a reductionist view of patriotism and patriarchy. As part of the language of possibility, authority as an emancipatory practice provides the scaffolding with which one can connect the purpose of schooling to the imperatives of what Benjamin Barber calls a "strong democracy," a democracy characterized by citizens capable of seriously confronting public issues through ongoing forms of public debate and social action. ${ }^{36}$

In our view, the most important referent for this particular view of authority rests in a commitment to address the many instances of suffering that characterize the present society. This suggests a recognition and identification with "the perspective of those people and groups who are marginal and exploited." ${ }^{37}$ In its practical dimension, such a commitment represents a break from the bonds of isolated liberal individuality and a desire to engage with others in political struggles that challenge the existing order of society as being institutionally repressive and unjust. It is important to note that transformative intellectuals can serve to act, as Welch points out, as bearers of dangerous memory. ${ }^{38}$ This means that such intel-

${ }^{36}$ Barber, Strong Democracy: Participating Politics for a New Age Theology of Liberation (Berkeley: University of California Press, 1984).

${ }^{37}$ Sharon Welch, Communities of Resistance and Solidarity (New York: Orbis Press, 1985), p. 31.

${ }^{38}$ Welch, Communities of Resistance, p. 37. 
lectuals can link knowledge to power by bringing to light and teaching the subjugated histories, experiences, stories, and accounts of those who suffer and struggle within conditions that are rarely made public or analyzed through the official discourses of public schooling. Thus, we can point to the histories of women, blacks, working-class groups, and others whose histories challenge the moral legitimacy of the structures of society and therefore contain knowledge too "dangerous" to make visible. Of course, teachers of "dangerous memory" must do more than excavate historical reason and subjugated knowledge; they must also make clear that people are called to struggle, that political alternatives do in fact exist, and that such buried knowledge needs to be appropriated in the interest of creating more critically democratic societies.

\section{Rethinking the Nature of Teacher Education}

We would like to bring the foregoing discussion to bear on the more practical mission of reconstructing teacher education programs around a new vision of democratic schooling and teaching for critical citizenship. Consequently, we shall devote the remainder of our discussion to outlining, in more detailed and programmatic terms, what we feel are some essential components and categories for a teacher education curriculum and a critical pedagogy for the schools.

As we have argued, most teacher education programs have been, and continue to be, entirely removed from a vision and a set of practices dedicated to the fostering of critical democracy and social justice. A repeated criticism made by educators working within the radical tradition has been that, as it currently exists, teacher education rarely addresses either the moral implications of societal inequalities within our present form of industrial capitalism or the ways in which schools function to reproduce and legitimate these inequalities. ${ }^{39}$

Usually when classroom life is discussed in teacher education programs, it is presented fundamentally as a one-dimensional set of rules and regulative practices, rather than as a cultural terrain where a variety of interests and practices collide in a constant and often chaotic struggle for dominance. Thus, prospective teachers frequently receive the impression that classroom culture is essentially free from ambiguity and contradiction. According to this view, schools are supposedly devoid of all vestiges of contestation, struggle, and cultural politics. ${ }^{40}$ Furthermore, classroom reality is rarely presented as if it were socially constructed, historically determined, and reproduced through institutionalized relationships of class, gender, race, and power. Unfortunately, this dominant conception of schooling vastly contradicts what the student teacher often experiences during his or her practicum or fieldsite work, especially if the student is placed in a school largely populated by economically disadvantaged and disenfranchised students. Yet, student teachers are nevertheless instructed to view schooling as a neutral terrain devoid of power and politics. It is against this transparent depiction of schooling that prospective teachers, more often than not, view their own ideologies and

${ }^{39}$ Zeichner, "Alternative Paradigms"; Henry A. Giroux, Ideology, Culture, and the Process of Schooling (Philadelphia: Temple University Press, 1981); and John Sears, "Rethinking Teacher Education: Dare We Work Toward a New Social Order?" Journal of Curriculum Theorizing, 6 (1985), 24-79.

${ }^{40}$ Of course, this is not true for all teacher education programs, but it does represent the dominant tradition characterizing them; see Zeichner, "Alternative Paradigms." 
experiences through a dominant theoretical and cultural perspective that remains largely unquestioned. Most important, teachers in this situation have no grounds upon which to question the dominant cultural assumptions that shape and structure the ways in which they respond to and influence student behavior.

Consequently, many student teachers who find themselves teaching workingclass or minority students lack a well-articulated framework for understanding the class, cultural, ideological, and gender dimensions that inform classroom life. As a result, cultural differences among students often are viewed uncritically as deficiencies rather than as strengths, and what passes for teaching is in actuality an assault on the specific histories, experiences, and knowledges that such students use both to define their own identities and to make sense of their larger world. We use the term "assault" not because such knowledge is openly attacked - but because it is devalued through a process that is at once subtle and debilitating. What happens is that within the dominant school culture, subordinate knowledge is generally ignored, marginalized, or treated in a disorganized fashion. Such knowledge is often treated as if it did not exist, or treated in ways that disconfirm it. Conversely, ideologies that do not aid subordinate groups in interpreting the reality they actually experience often pass for objective forms of knowledge. In this process prospective teachers lose an understanding of the relationship between culture and power as well as a sense of how to develop pedagogical possibilities for their students from the cultural differences that often characterize school and classroom life. In the section that follows, we will discuss the elements we feel should constitute a new model of teacher education, one that addresses the above issue more specifically.

\section{Teacher Education as Cultural Politics}

Our concern here is with reconstituting the grounds upon which teacher education programs are built. This means developing an alternative form of teacher education curriculum that supports what we call the construction of a cultural politics. In our view, such a programmatic approach to teacher education conceptualizes schooling as taking place within a political and cultural arena where forms of student experience and subjectivity are actively produced and mediated. In other words, we wish to stress the idea that schools do not merely teach academic subjects, but also, in part, produce student subjectivities or particular sets of experiences that are in themselves part of an ideological process. Conceptualizing schooling as the construction and transmission of subjectivities permits us to understand more clearly the idea that the curriculum is more than just an introduction of students to particular subject disciplines and teaching methodologies; it also serves as an introduction to a particular way of life. ${ }^{41}$

At this point, we must forego a detailed specification of teaching practices and instead attempt to briefly sketch out particular areas of study crucial to the devel-

${ }^{41}$ See John Ellis, "Ideology and Subjectivity," in Culture, Media, Language, ed. Stuart Hall, Dorothy Hobson, Andrew Lowe, and Paul Willis (Hawthorne, Australia: Hutchinson, 1980), pp. 186-194; see also Julian Henriques, Wendy Hollway, Cathy Urwin Couze Venn, and Valerie Walkerdine, Changing the Subject (New York: Methuen, 1984). 
opment of a reconceptualized teacher education curriculum. We assign the term "cultural politics" to our curriculum agenda because we feel that this term permits us to capture the significance of the sociocultural dimension of the schooling process. Furthermore, the term allows us to highlight the political consequences of interaction between teachers and students who come from dominant and subordinate cultures. A teacher education curriculum as a form of cultural politics assumes that the social, cultural, political, and economic dimensions are the primary categories for understanding contemporary schooling. ${ }^{42}$ Within this context, school life is conceptualized not as a unitary, monolithic, and ironclad system of rules and regulations, but as a cultural terrain characterized by varying degrees of accommodation, contestation, and resistance. Furthermore, school life is understood as a plurality of conflicting languages and struggles, a place where classroom and street-corner cultures collide and where teachers, students, and school administrators often differ as to how school experiences and practices are to be defined and understood.

The imperative of this curriculum is to create conditions for student selfempowerment and self-constitution as an active political and moral subject. We are using the term "empowerment" to refer to the process whereby students acquire the means to critically appropriate knowledge existing outside of their immediate experience in order to broaden their understanding of themselves, the world, and the possibilities for transforming the taken-for-granted assumptions about the way we live. Stanley Aronowitz has described one aspect of empowerment as "the process of appreciating and loving oneself." ${ }^{43}$ In this sense, empowerment is gained from knowledge and social relations that dignify one's own history, language, and cultural traditions. But empowerment means more than self-confirmation. It also refers to the process by which students are able to interrogate and selectively appropriate those aspects of the dominant culture that will provide them with the basis for defining and transforming, rather than merely serving, the wider social order.

The project of "doing" a teacher education curriculum based on cultural politics consists of linking critical social theory to a set of stipulated practices through which student teachers are able to dismantle and critically examine preferred educational and cultural traditions, many of which have fallen prey to an instrumental rationality that either limits or ignores democratic ideals and principles. One of our main concerns focuses on developing a language of critique and demystification that is capable of analyzing the latent interests and ideologies that work to socialize students in a manner compatible with the dominant culture. We are equally concerned, however, with creating alternative teaching practices capable of empowering students both inside and outside of schools. While it is impossible to provide a detailed outline of the courses of a curriculum for cultural politics, we want to comment on some important areas of analysis that should be central to such a program. These include the critical study of power, language, culture, and history.

\footnotetext{
${ }^{42}$ Henry A. Giroux and Roger Simon, "Curriculum Study and Cultural Politics," Journal of Education, 166 (1984), 226-238.

${ }^{43}$ Stanley Aronowitz, "Schooling, Popular Culture, and Post-Industrial Society: Peter McLaren Interviews Aronowitz," Orbit, 17 (1986), 18.
} 


\section{Power}

A pivotal concern of a teacher education curriculum that subscribes to a cultural politics approach is to assist student teachers in understanding the relationship between power and knowledge. Within the dominant curriculum, knowledge is often removed from the issue of power and is generally treated in a technical manner; that is, it is seen in instrumental terms as something to be mastered. That such knowledge is always an ideological construction linked to particular interests and social relations generally receives little consideration in teacher education programs. An understanding of the knowledge/power relationship raises important issues regarding what kinds of knowledge educators can provide to empower students, not only to understand and engage the world around them, but also to exercise the kind of courage needed to change the social order where necessary. Of considerable concern, then, is the need for student teachers to recognize that power relations correspond to forms of school knowledge that both distort the truth and produce it. That is, knowledge should be examined not only for the ways in which it might misrepresent or mediate social reality, but also for the ways in which it actually reflects peoples' experiences and, as such, influences their lives. Understood in this way, knowledge not only reproduces reality by distorting or illuminating the social world; it also has the more concrete function of shaping the day-to-day lives of people through their felt, relatively unmediated world of commonsense assumptions. This suggests that a curriculum for democratic empowerment must not only examine the conditions of school knowledge in terms of how it is produced and what particular interests it might represent, but should also scrutinize the effects of such knowledge as it is lived day-to-day. In short, prospective teachers need to understand that knowledge does more than distort, it also produces particular forms of life. Finally, in Michel Foucault's terms, knowledge contains hopes, desires, and wants that resonate positively with the subjective experience of a particular audience and such knowledge needs to be analyzed for the utopian promises often implicit in its claims. ${ }^{44}$

\section{Language}

In traditional and institutionally legitimated approaches to reading, writing, and second-language learning, language issues are primarily defined by technical and developmental concerns. While such concerns are indeed important, what is often ignored in mainstream language courses in teacher education programs is how language is actively implicated in power relations that generally support the dominant culture. An alternative starting point to the study of language recognizes the significance of Antonio Gramsci's notion that every language contains elements of a conception of the world. It is through language that we come to consciousness and negotiate a sense of identity, since language does not merely reflect reality, but plays an active role in constructing it. As language constructs meaning, it shapes our world, informs our identities, and provides the cultural codes for perceiving and classifying the world. This implies, of course, that within the available discourses of the school or the society, language plays a powerful role because it

\footnotetext{
${ }^{44}$ Foucault, "The Subject of Power," in Beyond Structuralism and Hermeneutics, ed. Hubert Dreyfus and Paul Rabinow (Chicago: University of Chicago Press, 1982), p. 221.
} 
serves to "mark the boundaries of permissible discourse, discourage the clarification of social alternatives, and makes it difficult for the dispossessed to locate the source of their unease, let alone remedy it." 45 Through the study of language within the perspective of a cultural politics, prospective teachers can gain an understanding of how language functions to "position" people in the world, to shape the range of possible meanings surrounding an issue, and to actively construct reality rather than merely reflect it. As part of language studies, student teachers would become more knowledgeable about and sensitive to the omnipresence and power of language as constitutive of their own experiences and those of their potential students. ${ }^{46}$ Student teachers would also benefit from an introductory understanding of European traditions of discourse theory and the textual strategies that characterize their methods of inquiry. ${ }^{47}$ Furthermore, through an exposure to the semiotics of mass and popular cultures, students could at least learn the rudimentary methods of examining the various codes and meanings that are constitutive of both their own personal constructions of self and society and those of the students they work with during their practicum or on-site sessions.

\section{History}

The study of history should play a more expansive role in teacher education programs. ${ }^{48} \mathrm{~A}$ critical approach to history would attempt to provide student teachers with an understanding of how cultural traditions are formed; it would also be designed to bring to light the various ways that curricula and discipline-based texts have been constructed and read throughout different historical periods. Furthermore, such an approach would be self-consciously critical of the problems surrounding the teaching of history as a school subject, since what is conventionally taught overwhelmingly reflects the perspectives and values of white, middle-class males. Too often excluded are the histories of women, minority groups, and indigenous peoples. This exclusion is not politically innocent when we consider how existing social arrangements are partly constitutive of and dependent upon the subjugation and elimination of the histories and voices of those groups marginalized and disempowered by the dominant culture. In addition, the concept of history can also help illuminate what kinds of knowledge are deemed legitimate and promulgated through the school curriculum. Conventional emphasis on chronological history "which traditionally saw its object as somehow unalterably 'there,' given, waiting only to be discovered" 49 would be supplanted by a focus on how specific educational practices can be understood as historical constructions related to

${ }^{45}$ T. J. Jackson Lears, "The Concept of Cultural Hegemony: Problems and Possibilities," American Historical Review, 90 (1985), 569-570.

${ }^{46}$ Gary Waller, "Writing, Reading, Language, History, Culture: The Structure and Principles of the English Curriculum at Carnegie-Mellon University." Unpublished manuscript, Carnegie-Mellon University, 1985, p. 12.

${ }^{47}$ We are primarily referring to the French school of discourse theory, as exemplified in the writings of Foucault; see his The Archaeology of Knowledge, trans. A. M. Sheridan Smith (London: Tavistock; see also the following works by Foucault: Language, Counter-Memory, Practice: Selected Essays and Interviews, Donald F. Bouchard, trans. Donald F. Bouchard and Sherry Simon (Ithaca: Cornell University Press, 1979); and "Politics and the Study of Discourse," Ideology and Consciousness, 3 (1978), 7-26.

${ }^{48}$ Waller, "Writing, Reading, Language," p. 12.

49 Waller, "Writing, Reading, Language," p. 14. 
the economic, social, and political events of a particular time and place. It is primarily through this form of historical analysis that students can recover what we referred to previously as "subjugated knowledges." 50 Our use of this term directs us to those aspects of history in which criticism and struggle have played a significant role in defining the nature and meaning of educational theory and practice. For example, students will have the opportunity to examine critically the historical contexts and interests at work in defining what forms of school knowledge become privileged over others, how specific forms of school authority are sustained, and how particular patterns of learning become institutionalized.

Within the format of a curriculum as a form of cultural politics, it is also necessary that the study of history be theoretically connected to both language and reading. In this context, language can be subsequently studied as "the bearer of history" and history can be analyzed as a social construction open to critical examination. The important linkage between reading and history can be made by emphasizing that "reading occurs within history and that the point of integration is always the reader." ${ }^{51}$ In analyzing this relationship, teachers can focus on the cultural meanings that students use to understand a text. Such a focus will better equip student teachers to understand how the process of reading occurs within a particular student's cultural history and in the context of his or her own concerns and beliefs. This will also assist student teachers to become more critically aware of how students from subordinate cultures bring their own sets of experiences, as well as their own dreams, desires, and voices to the reading act.

\section{Culture}

The concept of culture, varied though it may be, is essential to any teacher education curriculum aspiring to be critical. We are using the term "culture" here to signify the particular ways in which a social group lives out and makes sense of its "given" circumstances and conditions of life. ${ }^{52}$ In addition to defining culture as a set of practices and ideologies from which different groups draw to make sense of the world, we also want to refashion the ways in which cultural questions become the starting point for understanding the issue of who has power and how it is reproduced and manifested in the social relations that link schooling to the wider social order. The link between culture and power has been extensively analyzed in radical social theory over the past ten years. It is therefore possible to offer three insights from that literature that are particularly relevant for illuminating the political logic that underlies various cultural/power relations. First, the concept of culture has been intimately connected with the question of how social relations are structured within class, gender, and age formations that produce forms of oppression and dependency. Second, culture has been analyzed within the radical perspective not simply as a way of life, but as a form of production through which dif-

\footnotetext{
so Foucault, "Two Lectures," in Power/Knowledge, ed. Colin Gordon (New York: Pantheon, 1980), pp. 78-108.

s1 Waller, "Writing, Reading, Language," p. 14.

52 Henry A. Giroux, Ideology Culture, and the Process of Schooling (Philadelphia: Temple University Press, 1981).
} 
ferent groups in either their dominant or subordinate social relations define and realize their aspirations through asymmetrical relations of power. Third, culture has been viewed as a field of struggle in which the production, legitimation, and circulation of particular forms of knowledge and experience are central areas of conflict. What is important here is that each of these insights raises fundamental questions about the ways in which inequalities are maintained and challenged in the sphere of culture.

The study of cultures-or, more specifically, what has come to be known as "cultural studies" - should become the touchstone of a teacher education curriculum. We feel this to be the case because cultural studies can provide student teachers with the critical categories necessary for examining school and classroom relations as social and political practices inextricably related to the construction and maintenance of specific relations of power. Moreover, by recognizing that school life is often mediated through the clash of dominant and subordinate cultures, prospective teachers can gain some insight into the ways in which classroom experiences are necessarily intertwined with their students' home life and street-corner culture. This point is meant to be more than a rallying cry for relevance; rather, it asserts the need for prospective teachers to understand the meaning systems that students employ in their encounters with forms of dominant school knowledge and social relations. It is important, therefore, that student teachers learn to analyze expressions of mass and popular culture, such as music videos, television, and film. In this way, a successful cultural studies approach would provide an important theoretical avenue for teachers to comprehend how ideologies become inscribed through representations of everyday life.

\section{Towards a Critical Pedagogy for the Classroom}

In the previous sections we have highlighted the importance of viewing schools as social and political sites involved in the struggle for democracy. In addition, we have reconsidered the relationship between authority and teacher work and have attempted to develop the theoretical rudiments of a program in which teacher education would be viewed as a form of cultural politics. In this final section, we shift the focus from questions of institutional purpose and teacher definition to the issues of critical pedagogy and student learning. In so doing, we point to some of the fundamental elements that we believe can be used to construct a critical pedagogy, one in which the issue of student interests or motivation is linked to the dynamics of self- and social empowerment. We wish to underscore here that the public schools shape and reinforce the attitudes that prospective teachers bring to their clinical experiences. By focusing on some of the theoretical elements that constitute a critical pedagogy, we attempt to clarify the link between our notion of a teacher education curriculum as a form of cultural politics and the actual dynamics of classroom pedagogy. With this in mind, we will now sketch out the rudiments of a critical discourse that defines classroom pedagogy within the parameters of a political project centering around the primacy of student experience, the concept of voice, and the importance of transforming schools and communities into democratic public spheres. 


\section{The Primacy of Student Experience}

The type of critical pedagogy we are proposing is fundamentally concerned with student experience insofar as it takes the problems and needs of the students themselves as its starting point. On the one hand, a pedagogy of student experience encourages a critique of dominant forms of knowledge and cultural mediation that collectively shape student experiences; on the other hand, it attempts to provide students with the critical means to examine their own particular lived experiences and subordinate knowledge forms. This means assisting students in analyzing their own experiences so as to illuminate the processes by which they were produced, legitimated, or disconfirmed. R. W. Connell and his associates in Australia provide a cogent direction for this type of curricular approach in their formulation of the kinds of knowledge that should be taught to empower workingclass students when they suggest:

that working-class kids get access to formal knowledge via learning which begins with their own experience and the circumstances which shape it, but does not stop there. This approach neither accepts the existing organization of academic knowledge nor simply inverts it. It draws on existing school knowledge and on what working-class people already know, and organizes this selection of information around problems such as economic survival and collective action, handling the disruption of households by unemployment, responding to the impact of new technology, managing problems of personal identity and association, understanding how schools work and why. ${ }^{53}$

Student experience is the stuff of culture, agency, and identity formation and must be given preeminence in an emancipatory curriculum. It is therefore imperative that critical educators learn how to understand, affirm, and analyze such experience. This means not only understanding the cultural and social forms through which students learn how to define themselves, but also learning how to engage student experience in a way that neither unqualifiedly endorses nor delegitimates such experience. This suggests that, first of all, knowledge has to be made meaningful to students before it can be made critical. School knowledge never speaks for itself; rather, it is constantly filtered through the ideological and cultural experiences that students bring to the classroom. To ignore the ideological dimensions of student experience is to deny the ground upon which students learn, speak, and imagine. Judith Williamson addresses this issue well.

Walter Benjamin has said that the best ideas are no use if they do not make something useful of the person who holds them; on an even simpler level, I would add that the best ideas don't even exist if there isn't anyone to hold them. If we cannot get the "radical curriculum" across, or arouse the necessary interest in the "basic skills," there is no point to them. But in any case, which do we ultimately care more about: our ideas, or the child/student we are trying to teach them to? ${ }^{54}$

${ }^{53}$ Robert W. Connell, Dean J. Ashenden, Sandra Kessler, Gary W. Dowsett, Making the Difference: Schools, Families, and Social Division (Winchester, MA: Allen \& Unwin, 1982), p. 199; see also Peter McLaren, Schooling as a Ritual Performance: Towards a Political Economy of Educational Symbols and Gestures (London: Routledge \& Kegan Paul, 1986).

${ }^{54}$ Williamson, "Is There Anyone Here From a Classroom?," Screen, 26 (Jan./Feb. 1984), 24; see also Henry A. Giroux, "Radical Pedagogy and the Politics of Student Voice," Interchange, 17 (1986), 48-69. 
Students cannot learn "usefully" unless teachers develop an understanding of the various ways in which student perceptions and identities are constituted through different social domains. At stake is the need for student teachers to understand how experiences produced in the various domains and layers of everyday life give rise to the different voices students employ to give meaning to their worlds and, consequently, to their existence in the larger society. Of course, not all student experiences should be unqualifiedly affirmed or rendered legitimate since some of them undoubtedly will draw from an uncritical categorization and social construction of the world (as in racist and sexist stereotyping, for example). In this case, teachers must understand student experience as arising from multiple discourses and subjectivities, some of which must be interrogated more critically than others. It is crucial, therefore, that educators address the question of how aspects of the social world are experienced, mediated, and produced by students. Failure to do so will not only prevent teachers from tapping into the drives, emotions, and interests that give students their own unique voice, but will also make it equally difficult to provide the momentum for learning itself.

While the concept of student experience is being offered as central to a critical pedagogy, it should also be recognized as a central category of teacher education programs. This suggests that student practicums should be seen as sites where the question of how experience is produced, legitimated, and accomplished becomes an object of study for teachers and students alike. Unfortunately, most student practicums are viewed as either a rite of passage into the profession or merely a formal culminating experience in the teacher education program.

\section{Student Voice and the Public Sphere}

The concept of voice constitutes the focal point for a theory of teaching and learning that generates new forms of sociality as well as new and challenging ways of confronting and engaging everyday life. Voice, quite simply, refers to the various measures by which students and teachers actively participate in dialogue. It is related to the discursive means whereby teachers and students attempt to make themselves "heard" and to define themselves as active authors of their worlds. Displaying a voice means, to cite Mikhail Bakhtin, "retelling a story in one's own words." 55 More specifically, the term "voice" refers to the principles of dialogue as they are enunciated and enacted within particular social settings. The concept of voice represents the unique instances of self-expression through which students affirm their own class, cultural, racial, and gender identities. A student's voice is necessarily shaped by personal history and distinctive lived engagement with the surrounding culture. The category of voice, then, refers to the means at our disposal - the discourses available to us - to make ourselves understood and listened to, and to define ourselves as active participants in the world. However, as we have stressed previously, the dominant school culture generally represents and legitimates the voices of white males from the middle and upper classes to the exclusion of economically disadvantaged students, most especially females from minority backgrounds. ${ }^{56} \mathrm{~A}$ critical pedagogy takes into account the various ways in which

\footnotetext{
s5 As quoted in Harold Rosen, "The Importance of Story," Language Arts, 63 (1986), 234.

${ }^{56}$ For a thorough analysis of this, see Arthur Brittan and Mary Maynard, Sexism, Racism and Oppression (New York: Blackwell, 1984).
} 
the voices that teachers use to communicate with students can either silence or legitimate them.

The concept of voice is crucial to the development of a critical classroom pedagogy because it provides an important basis for constructing and demonstrating the fundamental imperatives of a strong democracy. Such a pedagogy attempts to organize classroom relationships so that students can draw upon and confirm those dimensions of their own histories and experiences which are deeply rooted in the surrounding community. In addition, by creating active links with the community, teachers can open up their classrooms to its diverse resources and traditions. This presupposes that teachers familiarize themselves with the culture, economy, and historical traditions that belong to the surrounding community. In other words, teachers must assume a pedagogical responsibility for attempting to understand the relationships and forces that influence their students outside of the immediate context of the classroom. This responsibility requires teachers to develop their curricula and pedagogical practices around those community traditions, histories, and forms of knowledge that are often ignored within the dominant school culture. This can, of course, lead to a deeper understanding on the part of both teachers and students of how both "local" and "official" knowledges get produced, sustained, and legitimated.

Teachers need to develop pedagogical practices that link student experiences with those aspects of community life that inform and sustain such experiences. For example, student teachers could compile oral histories of the communities in which they teach, which could then be used as a school and curricula resourceparticularly in reading programs. In addition, they could work in and analyze how different community social agencies function so as to produce, distribute, and legitimate particular forms of knowledge and social relations. This would broaden their notion of pedagogical practices and help them to understand the relevance of their own work for institutions other than schools. Similarly, prospective teachers could develop organic links with active community agencies such as business, religious organizations, and other public spheres in an attempt to develop a more meaningful connection between the school curriculum and the experiences that define and characterize the local community. The concept of voice can thus provide a basic organizing principle for the development of a relationship between knowledge and student experiences and, at the same time, create a forum for examining broader school and community issues. In other words, teachers must become aware of both the transformative strengths and structures of oppression of the community-at-large and develop this awareness into curriculum strategies designed to empower students toward creating a more liberating and humane society. In short, teachers should be attentive to what it means to construct forms of learning in their classrooms that enable students to affirm their voices within areas of community life, that is, within democratic public spheres needing constant criticism, safeguarding, and renewal.

Steve Tozer is worth quoting at length on this issue.

The process of fitting students for community life, then, is an effort to prepare students both for the existing community and to bring them to understand and to appreciate the historical values and ideas which point to a more ideal community than the one that exists . . . the teacher's duty is to recognize the historical 
ideals which make community life worth living, ideals upon which the larger society is founded: ideals of human dignity and equality, freedom, and mutual concern of one person for another. . . . This is not to say that teachers should prepare students for some nonexistent utopia. Rather, teachers must develop an understanding of the community as it exists and an understanding of what kind of people will be required to make it better. They can try to develop for themselves an ideal of the community their students should strive for, and they should help their students with the knowledge, the values and the skills they will need if they are to be resilient enough to maintain high standards of belief and conduct in an imperfect society. ${ }^{57}$

It is an unfortunate truism that when communities are ignored by teachers, students often find themselves trapped in institutions that not only deny them a voice, but also deprive them of a relational or contextual understanding of how the knowledge they acquire in the classroom can be used to influence and transform the public sphere. Implicit in the concept of linking classroom experiences to the wider community is the idea that the school is best understood as a polity, as a locus of citizenship. Within this locus, students and teachers can engage in a process of deliberation and discussion aimed at advancing the public welfare in accordance with fundamental moral judgments and principles. To bring schools closer to the concept of polity, it is necessary to define them as public spaces which seek to recapture the idea of critical democracy and community. In effect, we want to define teachers as active community participants whose function is to establish public spaces where students can debate, appropriate, and learn the knowledge and skills necessary to live in a critical democracy.

By public space we mean, as Hannah Arendt did, a concrete set of learning conditions where people come together to speak, to engage in dialogue, to share their stories, and to struggle together within social relations that strengthen rather than weaken possibilities for active citizenship. ${ }^{58}$ School and classroom practices should, in some manner, be organized around forms of learning which serve to prepare students for responsible roles as transformative intellectuals, as community members, and as critically active citizens outside of schools. ${ }^{59}$

\section{Conclusion}

We began this essay by arguing that teacher education should be seriously rethought along the lines of the critical democratic tradition, a tradition which, regrettably, has been all but excluded from the current debates on American schooling. We have argued that this tradition provides the basis for rethinking the relationship of schooling to the social order and for restructuring the education of

${ }^{57}$ Tozer, "Dominant Ideology and the Teacher's Authority," Contemporary Education, 56 (1985), 152-153.

s8 Arendt, The Human Condition (Chicago: University of Chicago Press, 1958).

${ }^{59}$ Attempts to link classroom instruction to community contexts is nowhere more important than during teachers' clinical experiences. On these occasions, prospective teachers should be assisted in making connections with progressive community organizations, especially those affiliated with local governmental council meetings and to interview community leaders and workers in various community agencies linked to the school. This enhances the possibility that prospective teachers will make critically reflective links between classroom practices and the ethos and needs of the surrounding social and cultural milieu. 
prospective teachers so as to prepare them for the role of transformative intellectual. Moreover, we have argued that teacher education programs must assume a central role in reforming public education and, in so doing, must assert the primacy of a democratic tradition in order to restructure school-community relations.

In our view, the search for a creative democracy undertaken at the beginning of the century by Dewey and others is presently in retreat, having been abandoned by liberals and radicals alike. This situation presents a dual challenge to critical educators: there is now an urgent need not only to resurrect the tradition of liberal democracy, but to develop a theoretical perspective that goes beyond it. In the current age of conservatism, public education must analyze its strengths and weaknesses against an ideal of critical democracy rather than the current corporate referent of the capitalist marketplace. Similarly, public education must fulfill the task of educating citizens to take risks, to struggle for institutional and social change, and to fight for democracy and against oppression both inside and outside of schools. Pedagogical empowerment necessarily goes hand-in-hand with social and political transformation.

Our position is indebted to Dewey but attempts to extend his democratic project. Dewey's struggle for democracy was primarily pedagogical and largely failed to develop an extended analysis of class relations and historically conditioned inequalities in society. Conversely, our position accentuates the idea that schools represent only one important site in the struggle for democracy. It is different from Dewey's view because it perceives the self- and social empowerment of students as involving not just the politics of classroom culture, but also political and social struggle outside of school sites. Such an approach acknowledges that critical pedagogy is but one intervention - albeit a crucial one - in the struggle to restructure the ideological and material conditions of everyday life. We are convinced that teacher education institutions and public schools can and should play an active and productive role in broadening the possibilities for the democratic promise of American schooling, politics, and society. 
This material has been reprinted with permission of the Harvard Educational Reviewfor personal use only. Any other use, print or electronic, will require written permission from the Review. For more information, please visit www.harvardeducationalreview.org or call 1-617-495-3432.

Copyright $\odot$ by the President and Fellows of Harvard College. All rights reserved.

The Harvard Educational Reviewis an imprint of the Harvard Education Publishing Group, publishers of the Harvard Education Letter and books under the imprint Harvard Education Press. HEPG's editorial offices are located at 8 Story Street, First Floor, Cambridge, MA 02138, tel. 617-495-3432, or email to hepg@harvard.edu. 